\title{
THREE CASES ILLUSTRATING THE PRESENCE OF ARGENTAFFIN (KULTSCHITZKY) CELLS IN THE HUMAN GALL-BLADDER
}

\author{
BY \\ A. C. CHRISTIE \\ From the Department of Pathology, Royal Cancer Hospital, London
}

(RECEIVED FOR PUBLICATION MARCH 29, 1954)

Occasionally typical argentaffin (Kultschitzky) cell or so-called "carcinoid" tumours have been described in the human gall-bladder (Joël, 1929; Porter and Whelan, 1939; Bosse, 1943), although I have found no mention in textbooks of histology or pathology of the presence of such cells in the mucosa. There is, however, one case report (Kerr and Lendrum, 1936) of a papilloma of this organ covered with intestinal epithelium containing both Paneth and argentaffin cells. I propose to describe three cases in which the latter type was present.

\section{Material and Methods}

The material was obtained from operation cases in which extra sections were cut from routine formalin-fixed paraffin blocks and stained by an alkaline silver method, either that of Masson and Hamperl as described by Jacobson (1939) or Gomori's (1948) hexamine-silver nitrate technique. In Case 3 the argentaffin cells were numerous and several histochemical stains were applied.

Being surgical material, most of the gall-bladders examined showed evidence of chronic inflammation. Nicholson (1923) has already given a masterly description of the pathological changes in chronic inflammation and, in particular, has drawn attention to areas of mucous gland formation, a phenomenon which he has referred to as indirect metaplasia. He found such areas in 24 out of 36 inflamed organs removed at operation and remarked that the percentage would probably have been increased had more sections been examined. He mentioned that Aschoff (1905), Schridde (1909), and Bodnár (1922) had previously drawn attention to the presence of mucous glands upon the surface of the fundus of the inflamed gall-bladder. Schridde (1909) also demonstrated the origin of these glands from the epithelium of Luschka's tubes in a case of cholecystoduodenal fistula.
Nicholson demonstrated how these tubular mucous glands change their type in a high proportion of cases and assume all the structural characters of gastric glands identical with those of the pylorus or those of Brunner. His Fig. 6 confirms this finding and presents a very similar picture to that seen in numerous areas in each of the three cases described below. Seventeen of Nicholson's series of 24 gall-bladders which contained mucous glands possessed those of the gastric type as well in varying numbers and in all stages of differentiation. He analysed the changes that eventually end in the formation of such gastric? glands in the gall-bladder and considered that they were of two kinds, namely, regressive, leading to the production of tubular mucous glands and other changes characteristic of the intestines, and progressive, culminating in the production of typical glands of the gastric type. (He considered Brunner's glands to be of the gastric type.)

As Nicholson has given such a full description of the changes in the gall-bladder epithelium in chronic inflammatory lesions, it only remains for me to demonstrate that argentaffin cells also occur both in the high columnar epithelium covering the surface of the mucous membrane and in the glandular acini. Morphologically the cells are almost always conical with a broad base in contact with the basement membrane and tapering towards a narrow elongated apex, which usually falls short of the lumen of the gland or the free mucosal surface as the case may be. The nucleus is usually situated near the middle of the cell and is vesicular with chromatin aggregations often more or less evenly distributed beneath the nuclear membrane (Fig. 3): such a nuclear pattern has been beautifully depicted by Ciaccio (1906). The intracellular granules lie between the nucleus and the basement membrane, that is, they are infranuclear. The histological appearances of these 
cells are, in fact, identical with those of the intestinal argentaffin cells which have been fully described by other workers (Cordier, 1926 ; Masson, 1928 ; Gillman, 1942).

\section{Case Reports}

Case 1.-The wall of the gall-bladder, that of a man aged 71 , is up to $0.3 \mathrm{~cm}$. thick and its mucosa in some places is thrown into irregular papillary processes and in others shows both Luschka's tubes penetrating into the muscularis and foci of glandular acini, the latter arising both from the surface epithelium and from the tubes.

Scattered very irregularly amongst the high columnar cells covering the papillary processes are cells with alkaline silver-reducing infranuclear granules which morphologically resemble intestinal argentaffin cells (Fig. 1). Occasionally such cells are present in the glandular acini, a feature also depicted in Fig. 1. Goblet cells are rarely seen on the surface epithelium, and, when present, bear no relation to the argentaffin cells : both apparently are scattered indiscriminately and very irregularly amongst the high columnar cells. Paneth cells are not present. The underlying wall is thickened and its musculature is partly replaced by fibro-cellular connective tissue. The submucosa is only sparsely peppered with chronic inflammatory cells ; in fact, the original chronic infective process shows no histological evidence of activity.

Case 2.-The gall-bladder, that of a woman aged 60 , measures $9.5 \mathrm{~cm}$. in length and up to $2.8 \mathrm{~cm}$. in diameter, with a wall averaging $0.2 \mathrm{~cm}$. in thickness. Its mucosa has a wrinkled surface.

Microscopically there is a considerable overgrowth of fibrous tissue involving all three coats. Approximately $5.0 \mathrm{~cm}$. of mucosal surface is included in the sections, although, in parts, the covering epithelium is denuded. Luschka's tubes penetrate deeply into the mucosa, especially in one area where there are

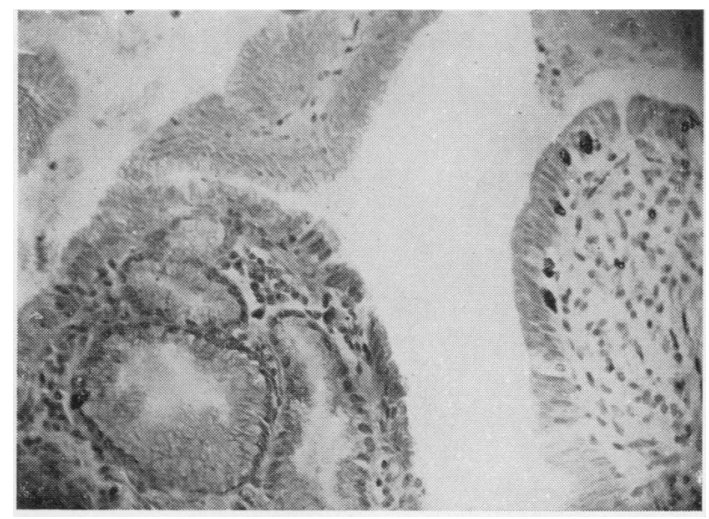

Fig. 1.-Case 1, showing argentaffin cells, both on a papillary projection of the mucosa (right side) and a solitary cell in a glandular acinus (lower left corner). Masson-Hamperl's ammoniacal silver stain. $\times 200$.

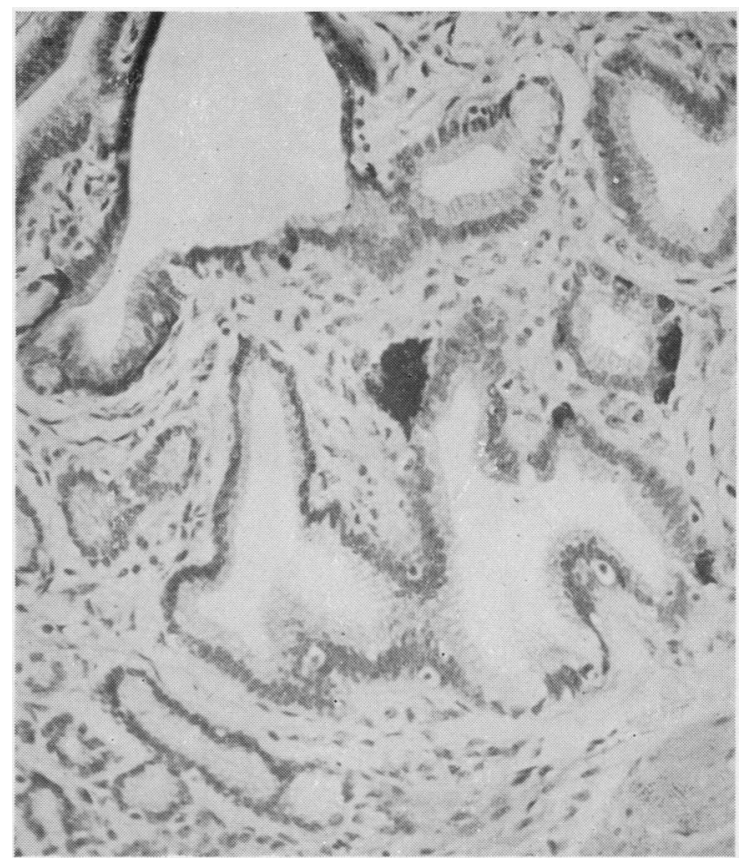

FIG. 2.-Case 2, showing argentaffin cells, both solitary and in groups, in glandular acini. One group (in centre) has been sectioned obliquely. Masson-Hamperl's ammoniacal silver
stain. $\times 200$.

numerous coiled glands, many being of Nicholson's "gastric" type. Here and there in this nidus of acini are cells morphologically resembling the argentaffin cells of the intestine and containing infranuclear ammoniacal silver-reducing granules (Fig. 2). In one area, in adjoining acini (almost certainly part of the same coiled gland system), there are two clumps of such cells, the larger containing eight cells in apposition. In addition, there is an occasional isolated argentaffin cell in the same gland system (Fig. 2). When present in mucous glands these cells are, as in Brunner's glands, usually found lying at the periphery of the acinus against the basement membrane and separated from the lumen by mucous cells. In the papilliferous mucosa overlying this group of glands there are goblet cells and an occasional argentaffin cell amidst the high columnar epithelial cells. Elsewhere in the mucosa there are numerous small foci of glandular acini which, however, contain no argentaffin cells. Paneth cells are absent throughout the mucosa.

Case 3. - The specimen is that from a woman aged 49. The macroscopic description of this specimen is not available. Microscopically the wall is slightly thickened due to a moderate overgrowth of fibrous tissue involving the submucosa, muscularis, and subserosa. The covering mucosa is papilliferous in places and partly denuded of its overlying epithelium. The most prominent feature throughout most of the mucosa is a large number of tubular glands which 


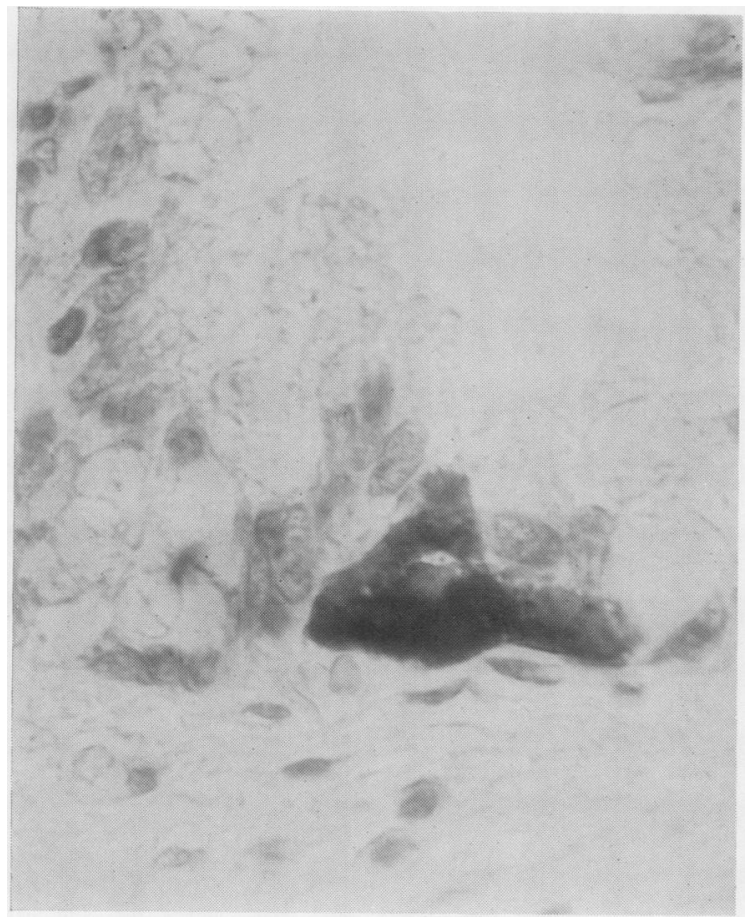

Fig. 3.-Case 3, showing a clump of argentaffin cells in a glandular acinus. In the cell on the extreme right of the clump, the typical chromatin pattern in the nucleus can be discerned. Gomori's hexamine-silver nitrate stain. $\times 900$

have arisen, both from the surface epithelium and from deeply penetrating Luschka's tubes, the latter having penetrated almost completely through the muscularis in some places. The glands are of both the types described by Nicholson (1923), but the majority belong to his " gastric" variety and do, in fact, closely resemble Brunner's glands. The mucus in both types of glands gives a strongly positive reaction with the periodic-acid-Schiff stain for demonstrating the 1,2-glycol linkage (as would occur in mucopolysaccharides). Argentaffin cells are very unevenly distributed both amongst the glandular mucous cells and the tall columnar surface epithelium. Quite often they appear in clumps (Fig. 3), and in one relatively small group of glands, approximately $1 \mathrm{~mm}$. in diameter and just beneath the surface epithelium, 32 such cells are present, one clump alone containing 13 in apposition. In other areas numerous glandular acini are seen without a single argentaffin cell. No Paneth cells are present. The lamina propria is peppered with chronic inflammatory cells, mainly lymphocytes and plasma cells, and there is also capillary congestion of a moderate degree.

The cells under discussion react positively with the following stains, as in the case of the intestinal argentaffin cells : (1) Gomori's (1948) hexamine-silver nitrate method; (2) Cordier and Lison's (1930) diazo dye method : the technique as described by Jacobson
(1939) was used and the particular dye was " echtrotsalz" supplied by G. T. Gurr, London ; (3) Schmorl's ferric ferricyanide reduction test (Lillie and Burtner, 1953) : the granules stain a blue-green colour.

As only formalin-fixed, paraffin-embedded blocks are available, I have been unable to carry out Baker's acid haematein and pyridine extraction test for phospholipines. It has recently been shown (Christie, 1954) that the granules give a positive reaction in that they stain black in the first part of the test but not in the second-namely, the pyridine extraction-acid haematein test.

The chromaffin reaction could not be observed as it cannot be applied to tissues previously treated with formalin (Pearse, 1953).

\section{Discussion}

It is of paramount importance to decide first whether the cells under discussion are, in fact, argentaffin (Kultschitzky) cells such as occur in the intestine. That this is so can hardly be in doubt both from morphological appearances and staining reactions. Masson (1928) has given an admirable account of these cells in the human intestine and his description applies equally well to the cells described in the above three cases The granules within these cells also show histo chemical similarities with the intestinal argentaffin cells, for they give a positive reaction with Cordie and Lison's diazo dye technique, and also possess strongly reducing properties as shown by their ability to reduce both alkaline silver and ferric ferricyanide solutions. Whilst there are other substances occurring in the tissues which have equally strong reducing tendencies, they are not concentrated as fine granules in such a characteristic infranuclear position within the cell as in both these cells and in the typical argentaffin cell of the human intestinal mucosa.

It is very likely that such cells are frequently present in areas of intestinal metaplasia in inflamed gall-bladders but have not been noted, as the usual stains employed in routine histological work do not show them up very clearly, although. if the eosin be properly differentiated in the standard haematoxylin and eosin stain, they can be fairly easily discerned if sought after, for the characteristic granules are quite strongly eosinophilic (Masson, 1928). If the fixative employed contains alcohol then the granules are no longer seen by any staining technique even if formalin is also present in the fixative (Masson, 1928). However, formalin or formalin-containing mixtures are not the only fixatives of these cells as the granules are also preserved by potassium dichromate which gives them a yellow tint (even 
in the complete absence of formalin) and by osmium tetroxide which both preserves and blackens them due to its reduction to lower oxides.

Extensive histochemical studies could not be undertaken as only formalin-fixed tissue was available.

A point of considerable interest is the very uneven distribution of these cells. Sometimes, as in Cases 2 and 3 (Figs. 2 and 3, respectively), small clumps of them are seen. In the latter case such clumps contain more cells in apposition with one another than is usually seen in intestinal crypts of Lieberkühn. (I have previously once seen such an aggregation in a small cystic space lined by intestinal epithelium in a teratoma of the ovary.) They do not appear to be related in any specific way to the other cell types seen in metaplastic areas, such as goblet or mucous cells, but rather seem to occur for no apparent reason. In areas of intestinal metaplasia in the stomach, Paneth cells are also often seen, but they have not been observed in the above three cases, although, as mentioned above, Kerr and Lendrum (1936) did see them in their case of a papilloma covered with intestinal epithelium. Although there is some evidence of an active low-grade chronic infective process in the underlying mucosa in the second and third cases, the actual inflammatory lesion, as judged by histological evidence, is no more severe in the mucosa where the argentaffin cells are aggregated than where they are absent.

I have thus no explanation to offer concerning the function of these cells in the sites where they are present, or, for that matter, in the gall-bladder as a whole, except to say that it appears they are likely to occur in intestinal epithelium wherever it may arise. However, their presence in such epithelium is certainly not invariable and this is also the case in areas of intestinal epithelium in teratomata. The presence of these cells in clumps does suggest one or other (or perhaps both) of two possibilities ; namely, either that when conditions are such in a particular area for one cell-type to appear, then the stimulus affects the differentiation of more than one stem cell with the consequent production of a group of similar cells ; or, alternatively, that when one cell differentiates in a particular direction such as to form an argentaffin cell, then this cell remains true to type for a time at least, and divides to form similar daughter cells which, in turn, may divide to produce a group of specialized cells as in Fig. 3 of Case 3 . The presence of such clumps also suggests a likely site for possible tumour formation.

The occurrence of argentaffin cells in this organ, as in teratomata, indicates that direct absorption of precursor substances from the intestine is not esssential for the formation of the chemical substance (or substances) composing the granules.

\section{Summary}

Three cases are described in which chronically inflamed gall-bladders removed at operation contain areas of intestinal metaplasia with the presence of typical argentaffin (Kultschitzky) cells both amongst the high-columnar surface epithelial cells and within the mucous glands. The identity of these cells is established both on morphological and histochemical grounds. An explanation is thus afforded for the rare carcinoid tumours of this organ.

I am indebted to Mr. F. E. Speed for the photomicrographs and to Mr. C. G. Chadwin for the histological sections.

\section{REFERENCES}

Aschoff, L. (1905). Verh. dtsch. path. Ges., 9, 41.

Bodnár, L. (1922). Virchows Arch. path. Anat., 238, 359.

Bosse, M. D. (1943). Arch. Path., Chicago, 35, 898.

Christie, A. C. (1954). Nature, Lond., 173, 589.

Ciaccio, C. (1906). C. R. Soc. Biol., Paris, 60, 76.

Cordier, R. (1926). Arch. Biol., Paris, 36, 427.

- and Lison, L. (1930). Bull. Histol. Tech. micr., 7, 140.

Gillman, J. (1942). S. Afr. J. med. Sci., 7, 144.

Gomori, G. (1948). Arch. Path., Chicago, 45, 48.

Jacobson, W. (1939). J. Path. Bact., 49, 1.

Joël, W. (1929). Zbl. allg. Path. path. Anat., 46, 1.

Kerr, A. B., and Lendrum, A. C. (1936). Brit. J. Surg., 23, 615.

Lillie. R. D., and Burtner, H. J. (1953). J. Histochem. Cytochem., 1, 87.

Masson, P. (1928). Amer. J. Path., 4, 181

Nicholson, G. W. (1923). J. Path. Bact., 26, 399.

Pearse. A. G. E. (1953). Histochemistry. Theoretical and Applied, p. 346. Churchill, London.

Porter, J. E., and Whelan, C. S. (1939). Amer. J. Cancer, 36, 343.

Schridde, H. (1909). Die ortsfremden Epithelgewebe des Menschen. Fischer, Jena. 